\title{
A Novel GABA Receptor on Bipolar Cell Terminals in the Tiger Salamander Retina
}

\author{
Peter D. Lukasiewicz, ${ }^{1}$ Bruce R. Maple, ${ }^{2, a}$ and Frank S. Werblin ${ }^{2}$ \\ 1Departments of Ophthalmology, and Anatomy and Neurobiology, Washington University, St. Louis, Missouri 63110 and \\ ${ }^{2}$ Division of Ncurobiology, Department of Molecular and Cell Biology, University of California, Berkeley, California 94720
}

\begin{abstract}
We studied the pharmacology of the GABA receptors on bipolar cell terminals in the retinal slice preparation. Wholecell patch-clamp recordings were made from the somas of bipolar cells and GABA was puffed near their terminals, after synaptic transmission was blocked. GABA puffs evoked a large chloride current that was reduced by picrotoxin, but in many cells this current was insensitive to blockade by the competitive $G_{A B A_{A}}$ receptor antagonists bicuculline and SR95531. Pentobarbital, an enhancer of $\mathrm{GABA}_{A}$ receptormediated responses, did not significantly increase the magnitude of the current responses to GABA puffed at the bipolar cell terminals. To confirm the effectiveness of $G_{A B A}$ antagonists and pentobarbital in the slice preparation, we measured GABA currents in ganglion cells. In contrast to bipolar cells, the ganglion cell GABA responses were strongly reduced by both bicuculline and SR95531. In addition, pentobarbital strongly enhanced the action of GABA at the ganglion cells. The isomeric GABA agonists cis- and transaminocrotonic acid (CACA and TACA), elicited picrotoxinsensitive currents in both bipolar and ganglion cells. TACA was more effective than CACA at both cell types. In bipolar cells, TACA and CACA currents were relatively resistant to bicuculline blockade, but in ganglion cells both currents were reduced by bicuculline. GABA receptors on bipolar terminals appear to be pharmacologically different from the GABA receptors found on ganglion cell dendrites. The bipolar cell terminal GABA receptor pharmacology is similar to the pharmacology reported for the $\rho 1$ GABA receptor subunit that was isolated from retina and expressed in Xenopus oocytes (Cutting et al., 1991; Polenzani et al., 1991; Shimada et al., 1992). This receptor, which is both bicuculline and pentobarbital insensitive, has been called the $\mathrm{GABA}_{c}$ receptor (Johnston, 1986; Shimada et al., 1992). However, some bipolar cells were somewhat sensitive to blockade by bicuculline, suggesting that these cells had both $G_{A B A}$ and $\mathrm{GABA}_{C}$ receptors on their bipolar terminals.
\end{abstract} ina]

[Key words: GABA, synaptic transmission, bipolar cell, ret-

\footnotetext{
Received Jan. 25, 1993; revised Aug. 10, 1993; accepted Aug. 12, 1993.

We thank Drs. C. J. Dong and J. F. Muller for their helpful comments. This work was supported by NIH Grants EY00561 (F.S.W.), EY08922 (P.D.L.), Core Grant EY02687 (P.D.L.), and a Research to Prevent Blindness Miriam and Benedict Wolf Scholars Award (P.D.L.).

Correspondence should be addressed to Dr. Peter D. Lukasiewicz, Department of Ophthalmology, Washington University School of Medicine, St. Louis, MO 63110 .

aPresent address: Baylor College of Medicine, Cullen Eye Institute, Houston, TX 77030 .

Copyright (C) 1994 Society for Neuroscience $0270-6474 / 94 / 141202-11 \$ 05.00 / 0$
}

Results from a wide variety of studies indicate that the terminals of retinal bipolar cells receive synaptic input from GABAergic amacrine cells. GABA is a predominant inhibitory transmitter substance at the inner plexiform layer in the retinas of mudpuppy (Miller et al., 1981; Belgum et al., 1984), tiger salamander (Lukasiewicz and Werblin, 1990; Yang et al., 1991), fish (Marc et al., 1978; Yazulla et al., 1987), and rabbit (Wyatt and Daw, 1976). GABA is utilized by amacrine cells of tiger salamander (Werblin et al., 1988; Yang et al., 1991), goldfish (Marc et al., 1978; Yazulla et al., 1987; Muller and Marc, 1990), turtle (Hurd and Eldred, 1989; Muller et al., 1991), and cat (Chun and Wässle, 1989; Pourcho and Owczarzak, 1989; Hughes et al., 1991). In salamander, exogenously applied GABA has been shown to mimic the synaptic input to ganglion cells presumed to arise from amacrine cells (Miller et al., 1981; Belgum et al., 1984; Lukasiewicz and Werblin, 1990). Ultrastructural evidence has shown that amacrine cells feed back to bipolar cells in salamander (Dowling and Werblin, 1969; Wong-Riley, 1974). Salamander hipolar cells have been shown to be sensitive to GABA (Miller et al., 1981; Maple and Werblin, 1986; Atwell et al., 1987), indicating that some GABAergic amacrine cells feed back to bipolar terminals.

Patch recording has made it possible to measure the currents associated with neurotransmitter action at the synaptic terminals of bipolar cells. Recent studies have revealed that bipolar cells respond to exogenous application of GABA at their terminals (Maple and Werblin, 1986; Tachibana and Kaneko, 1987; Karschin and Wässle, 1990; Heidelberger and Matthews, 1991). These observations, along with the ultrastructural observations showing that GABA-accumulating or GABA-immunoreactive amacrine cells make synaptic contacts with bipolar cell terminals (Marc et al., 1978; Yazulla et al., 1987; Chun and Wässle, 1989; Pourcho and Owczarzak, 1989), arc consistent with GABA transmission from amacrine cells to bipolar terminals. However, the unique functional roles of these synapses in visual information processing in the inner retina remain to be determined.

Previous work has shown that GABA may be acting at bipolar terminals at several distinct $G A B A$ receptor subtypes. In tiger salamander, GABA acts at both $\mathrm{GABA}_{\mathrm{A}}$ (Maple and Werblin, 1986; Attwell et al., 1987) and $\mathrm{GABA}_{\mathrm{B}}$ receptors (Maguire et al., $1989 \mathrm{a}, \mathrm{b}$ ). In goldfish, GABA can act at $\mathrm{GABA}_{\mathrm{A}}$ receptors (Tachibana and Kaneko, 1987) and at yet another GABA receptor subtype that modulates calcium currents, but is pharmacologically distinct from $\mathrm{GABA}_{\mathrm{B}}$ receptors (Heidelberger and Matthews, 1991).

Bipolar cells receive large light-elicited inhibitory synaptic inputs (Lasansky, 1992). It was recently reported that these light- 
elicited inhibitory inputs were reduced by picrotoxin, but not by bicuculline or strychnine (Lukasiewicz and Werblin, 1992). This suggested that GABA-mediated synaptic input to bipolar cell terminals may be mediated by non-GABA $A_{A}$ receptors. We decided to reexamine the pharmacology of the responses evoked by GABA puffed at bipolar terminals to characterize the receptor mediating the light-elicited inhibitory inputs. We measured the effects of GABA agonists and antagonists on bipolar terminals in the tiger salamander retinal slice. We found that for many bipolar cells, the pharmacology of the GABA receptors on their terminals did not resemble that of the classical $\mathrm{GABA}_{\mathrm{A}}$ receptors, even though these receptors gate a chloride channel. The pharmacology of most GABA receptors on bipolar terminals was similar to the pharmacology of the $\mathrm{GABA}_{\mathrm{C}}$ receptor. Similar responses were recorded in frog oocytes after expression of retinal mRNA (Cutting et al., 1991; Polenzani et al., 1991; Shimada et al., 1992). GABA responses were blocked by picrotoxin, but were insensitive to blockade by SR95531 or bicuculline or to enhancement by pentoharbital. GABA receptors with similar pharmacology have been reported in frog tectal neurons (Nistri and Sivilotti, 1985; Sivilotti and Nistri, 1989), in white perch rod horizontal cells (Qian and Dowling, 1993), and in rat bipolar cells (Feigenspan et al., 1993). We also found that some bipolar cells were sensitive to bicuculline, suggesting that these cells had both $\mathrm{GABA}_{\mathrm{A}}$ and $\mathrm{GABA}_{\mathrm{C}}$ receptors present on their terminals. Rat bipolar cells appear to exhibit a similar GABA receptor heterogeneity (Feigenspan et al., 1993).

\section{Materials and Methods}

Whole-cell patch recording in retinal slices. Whole-cell patch recordings (Hamill et al., 1981) were made from bipolar cells and ganglion cells in retinal slice preparations (Werblin, 1978). The recording procedures have been described in detail elsewhere (Barnes and Werblin, 1986, 1987; Lukasiewicz and Werblin, 1988; Maguire et al., 1989a). Slices were prepared by placing a small square, cut from the back of the eye, vitreal side down onto a piece of Millipore filter. The sclera was pulled away, leaving the retina adhering to the filter. The retina and filter were then sliced with a tissue chopper at $150 \mu \mathrm{m}$ intervals. The slices were positioned so that the cells along the cut face of the slice could be viewed by the experimenter. The slices were immobilized by embedding the ends of the filter paper, which extended beyond the retina, in petroleum jelly.

Electrode and bathing solutions. Our standard intracellular solution consisted of (in MM) cesium sulfate, 65.2 ; cesium chloride, 6.5; HEPES, 5; magnesium chloride, 1; EGTA, 10; calcium chloride, 0.08; adjusted to $\mathrm{pH} 7.4$ with cesium hydroxide (the free calcium concentration was $\left.10^{-9} \mathbf{M}\right)$. Alternatively, we used the intracellular solution described by Mittman et al. (1990), which consisted of (in mM) cesium fluoride, 90.5; sodium chloride, 3.4; magnesium chloride, 0.4 ; calcium chloride, 0.4 ; EGTA, 11; and sodium HEPES, 10; adjusted to $\mathrm{pH} 7.7$ with cesium hydroxide (the free calcium concentration was $10^{-9} \mathbf{M}$ ). Results were identical with the two solutions, but fluoride greatly enhanced the probability of obtaining high-quality seals. In some experiments cesium chloride was partially substituted for cesium fluoride to alter the chloride equilibrium potential. The bathing medium contained (in $\mathrm{mM}$ ) sodium chloride, 112; potassium chloride, 2; calcium chloride, 2; magnesium chloride, 1; glucose, 5; and HEPES, 5; buffered to pH 7.8. Unless otherwise indicated, all chemicals were obtained from Sigma Chemical (St. Louis, MO). Picrotoxin, strychninc, pentobarbital (a gift from Dr. M. Price, Washington Univ., St. Louis) SR95531 (Research Biochemicals, Natick, MA), cis-aminocrotonic acid (CACA), and trans-aminocrotonic acid (TACA) (Tocris Neuramin, Bristol, UK) were added to the bathing medium without substitution. Synaptic transmission was blocked in some experiments using $0.1-1 \mathrm{~mm}$ cadmium chloride $\left(\mathrm{CdCl}_{2}\right)$. Although GABA currents could be measured in $\mathrm{CdCl}_{2}$, the amplitude of the GABAevoked current was reduced by $\mathrm{CdCl}_{2}$ in a dose-dependent manner, similar to that reported by Kaneko and Tachibana (1986) at turtle cone photoreceptor terminals. To optimize the size of the GABA currents, we blocked synaptic transmission with $20 \mathrm{~mm}$ magnesium chloride
$\left(\mathrm{MgCl}_{2}\right)$, which was substituted for an osmotically equivalent amount of sodium chloride. Experiments were performed at room temperature $\left(20-24^{\circ} \mathrm{C}\right)$.

A sewer pipe arrangement was used to apply drugs locally over the area of the slice under study. Flow through the sewer pipe was gravity driven at the rate of $1-2 \mathrm{ml} / \mathrm{min}$. Fine polyethylene tubing from ten 10 $\mathrm{ml}$ syringes was fastened inside a plastic gel-filling pipette tip. The pipette tip ( $400 \mu \mathrm{m}$ i.d.) was placed about $0.5 \mathrm{~mm}$ from the slice. Solutions flowed from the ganglion cell side to the photoreceptor side of the slice. In addition to the local sewer pipe perfusion, the entire recording chamber was continually superfused at a rate of $1-2 \mathrm{ml} / \mathrm{min}$ to accelerate washout of the applied drugs.

Liquid junction potential correction. Liquid junction potentials were determined by first placing the electrode in a bath containing the electrode solution to establish a zero offset potential. Then we measured the offset from the zero potential in normal media. The reference electrode was filled with $3 \mathrm{M}$ potassium chloride $(\mathrm{KCl})$. Membrane potential values in this article were corrected for junction potentials. The junction potential correction for the cesium sulfate/cesium chloride $\left(\mathrm{CsSO}_{4} / \mathrm{CsCl}\right)$ electrode solution was $-10 \mathrm{mV}$ and the junction potential correction for the cesium fluoride (CsF) electrode solution was $-6 \mathrm{mV}$.

Puff application of drugs. Current responses were elicited from bipolar cells by puffing GABA agonists near their axon terminals and from ganglion cells by puffing GABA agonists near their dendrites. Agonists were pressure ejected using a Picospritzer (General Valve Corp., Fairfield, NJ) driven by the digital output from a personal computer. The actual GABA (or muscimol) concentration at the cell was probably less than the pipette concentration (usually $1 \mathrm{~mm}$ ) because both puff pressure and puff duration were always reduced to give the smallest reproducible current response. The GABA concentration near the receptors was also reduced by diffusion and potent GABA uptake in the inner plexiform layer (Marc et al., 1978; Marc, 1986). Continuous superfusion of the preparation during the puff applications probably also reduced the concentration of GABA due to bulk flow.

Cell identification. Bipolar cells were identified by their location in the retinal slice and in some cases light stimulation. They were distinguished from amacrine cells by the lack of a transient inward sodium current and they were distinguished from horizontal cells by their higher input resistances. This identification was confirmed in many cells by staining. Cells were stained with I ucifer yellow CH (Aldrich Chemicals, Milwaukee, WI) by filling the patch electrodes with a $0.25-1 \%$ solution (Stewart, 1978). The stain diffused into the cell and its processes so identification could be made following the recording. Cell processes usually filled in less than $5 \mathrm{~min}$. Cells and processes were viewed using a Nikon mercury fluorescent epi-illuminator with an Omega Optical XF15 filter set (Brattleboro, VT). We identified ON and OFF bipolar cells based upon the ramification of their processes at different levels within the inner plexiform layer (Stell et al., 1977; Hare et al., 1986). Ganglion cells were similarly identified by the ramification of their dendrites at different depths in the inner plexiform layer (Famiglietti and Kolb, 1976; Famiglietti et al., 1977; Nelson et al., 1978).

Recording system. Cells were viewed with a Nikon Optiphot 2 microscope modified to have a fixed stage. A Nikon $40 \times$ long-workingdistance water-immersion objective with Hoffman Modulation contrast optics (Modulation Optics, Inc., Greenvale, NY) allowed easy visualization of cells on the surface of the slice. Electrodes were pulled from borosilicate glass (TW150F-4, World Precision Instruments, Sarasota, FL) with a Sachs-Flaming puller (Sutter Instruments, Novato, CA). Recordings were obtained with either a List L/M EPC7 (Medical Systems Inc., Greenvale, NY) or a Dagan 3900 (Minneapolis, MN) patchclamp amplifier. With resistance compensation the series resistance of the recording electrode was reduced to 5-20 M 2 . pCLAMP software (Axon Instruments, Foster City, CA) was used to generate voltage command outputs, acquire data, and trigger the drug application puffer. The data were digitized and stored with an IBM AT using a Labmaster DMA data acquisition board (Scientific Solutions, Solon, OH). Responses were filtered at $2 \mathrm{kHz}$ and sampled at $100 \mathrm{~Hz}$. Data were analyzed using CLAMPAN (Axon Instruments, Foster City, CA). Current responses from the pentobarbital experiments were integrated using CLAMPAN's integration subroutine.

\section{Results}

Distribution of $G A B A$ receptors

Sensitivity to GABA is highest at the bipolar cell terminals. Figure 1 shows a series of currents measured at the bipolar soma 


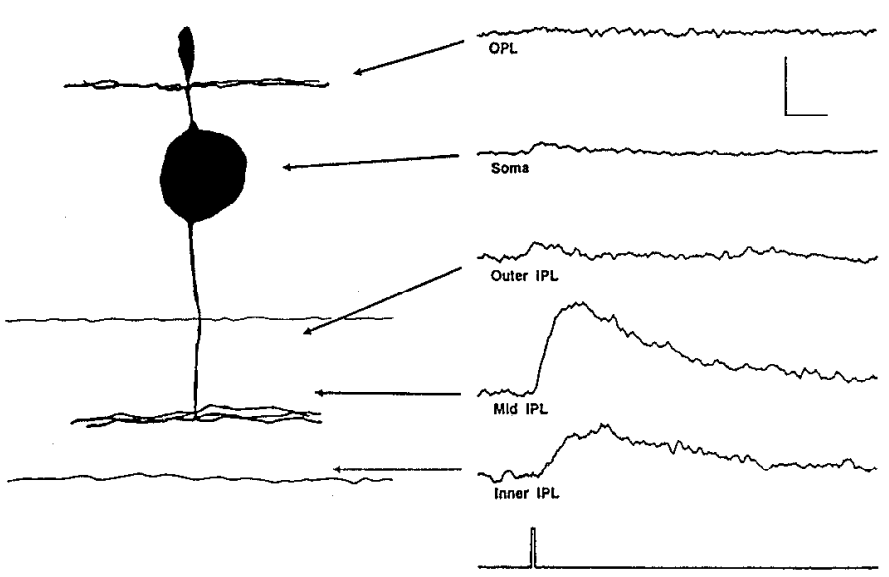

Figure 1. GABA sensitivity of a bipolar cell measured in the retinal slice. Morphology of the bipolar cell is represented by a sketch of the bipolar cell (left) made after the recordings were obtained when the cell was filled with Lucifer yellow. The terminals of this bipolar cell ramified in sublamina $B$ and suggest that this cell was an ON bipolar cell. Current responses to puffs of GABA at different locations along the cell are shown to the right. The trace beneath the current responses indicates the timing of solenoid that gated the GABA puffs. The responses were greatest for puffs presented at or near the axon terminals, and minimal for puffs presented at the cell body and at the dendrites. Synaptic transmission was blocked by including $1 \mathrm{~mm}$ cadmium chloride in the bathing medium. The holding potential was $-20 \mathrm{mV}$ and the calculated $E_{\mathrm{C} 1}$ was $-61 \mathrm{mV}$. The recording electrode contained the $\mathrm{CsSO}_{4} / \mathrm{CsCl}$ intracellular solution. $I P L$, inner plexiform layer; $O P L$, outer plexiform layer. Calibration: $20 \mathrm{pA}, 200 \mathrm{msec}$.

when $50 \mu \mathrm{M}$ GABA in the pipette was puffed at different positions along the bipolar cell. The bipolar cell is represented by a sketch made following the recording session after the cell was filled with Lucifer yellow. This cell was tentatively identified as an ON cell because its terminals ramified in sublamina B (Stell et al., 1977; Hare et al., 1986). The GABA-mediated currents elicited by the puffs were outward because the cell was held at $-20 \mathrm{mV}$ and the chloride reversal potential was $-61 \mathrm{mV}$. Synaptic transmission to the bipolar cell was blocked with $1 \mathrm{~mm}$ $\mathrm{CdCl}_{2}$ in the bath. The patch electrode contained cesium to block the potassium currents. The current was greatest when the puffs of GABA were presented at the bipolar terminal and minimal at the bipolar cell body or its dendrites. These data suggest that, in the slice, GABA receptors are more abundant at the bipolar cell's terminals compared to its soma or dendrites. This is similar to the GABA sensitivity profiles reported by Maple and Werblin (1986) in salamander, Tachibana and Kaneko (1987) in fish, and Karschin and Wässle (1990) in rat.

\section{GABA currents are mediated by chloride}

Figure $2 A$ shows a family of currents evoked by puffs of $1 \mathrm{~mm}$ GABA at the bipolar terminal. Each response was recorded when the bipolar cell was voltage clamped to the indicated potential. Synaptic transmission was blocked by including $20 \mathrm{~mm}$ $\mathrm{MgCl}_{2}$ in the bath for this and all subsequent experiments. The currents were inward at potentials negative to $-60 \mathrm{mV}$ but outward at more positive potentials. The control curve in Figure $2 B$ shows the current-voltage relation constructed by plotting the peak current responses as a function of holding potential. The reversal potential for the GABA-elicited current was near $-64 \mathrm{mV}$, the calculated $E_{\mathrm{C}}$ for the bipolar cell. The slope of the current-voltage relation was roughly linear, indicating that the GABA conductance was not significantly voltage dependent.
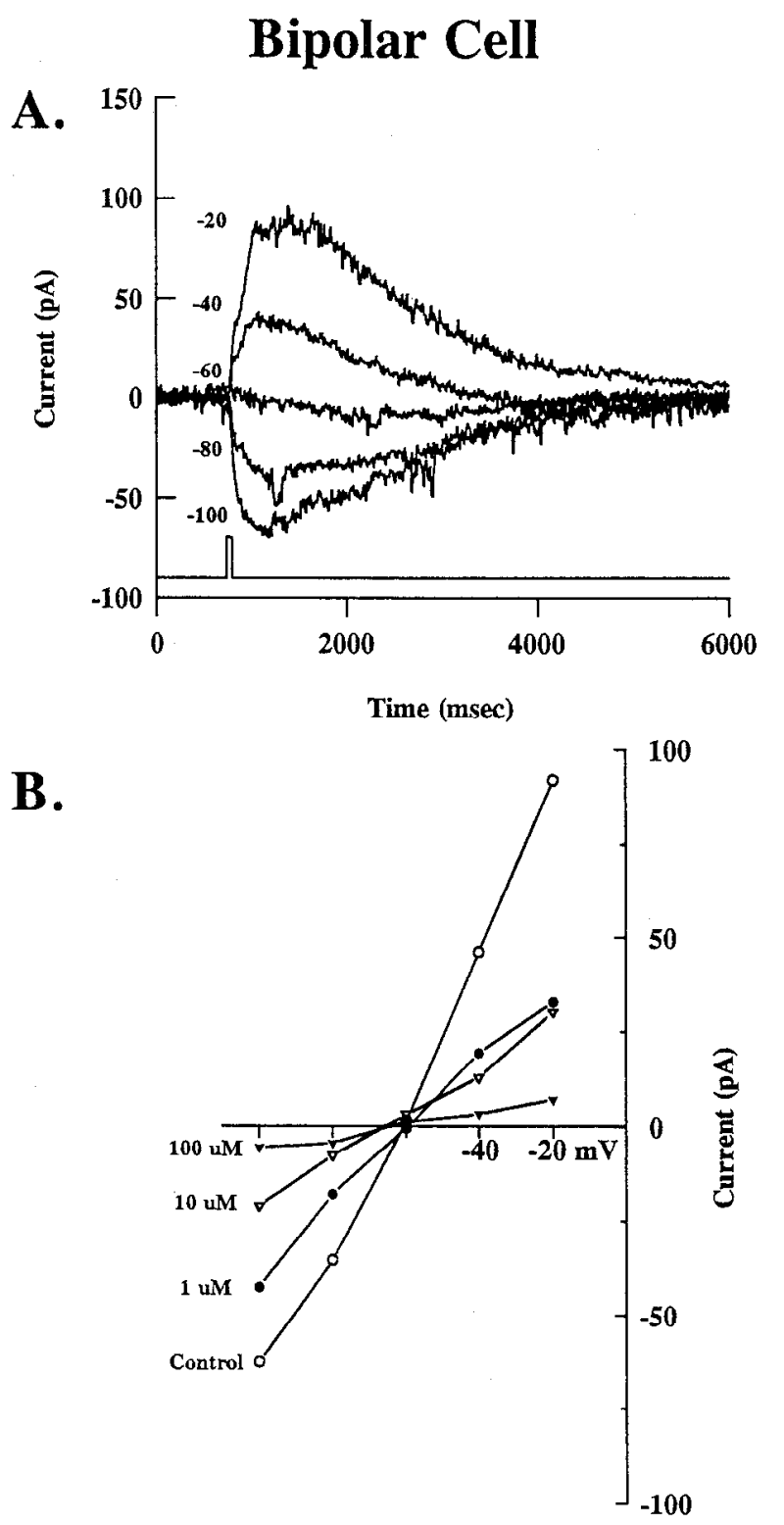

Figure 2. Current responses to GABA puffed at the bipolar cell terminal. $A$, Current responses to puffs of $1 \mathrm{~mm} \mathrm{GABA}$ when the cell was held at the indicated potentials. Synaptic transmission was blocked, in this and all subsequent figures, by including $20 \mathrm{mM} \mathrm{MgCl}$ in the bath (substituted for $\mathrm{NaCl}$ ). The time course of the solenoid that gated the puffer is indicated, in this and all subsequent figures, by the trace at the bottom. The currents reversed polarity near $-64 \mathrm{mV}$, the calculated $E_{\mathrm{C}} . B$, Current-voltage curves in the presence and absence of picrotoxin were constructed from the peak responses when the cell was held at

$100,80,60,40$, and $20 \mathrm{mV}$. Picrotoxin was applicd scqucntially at 1,10 , and $100 \mu \mathrm{M}$ and reduced the response in a dose-dependent manner. Picrotoxin, at all three doses, reduced the current at all potentials. The recording electrode contained the $\mathrm{CsSO}_{4} / \mathrm{CsCl}$ intracellular solution.

In several experiments the chloride concentration in the pipette was increased so that $E_{\mathrm{Cl}}$ was set to $-30 \mathrm{mV}$ (data not shown). GABA currents were nulled when the membrane was held at $-30 \mathrm{mV}$, indicating that the GABA response was largely mediated by chloride channels.

\section{Pharmacology of bipolar cell terminal GABA currents}

The $\mathrm{GABA}_{\mathrm{A}}$ receptor antagonists picrotoxin, bicuculline, and SR95531 were used to characterize the pharmacology of the 


\section{Bipolar Cell}
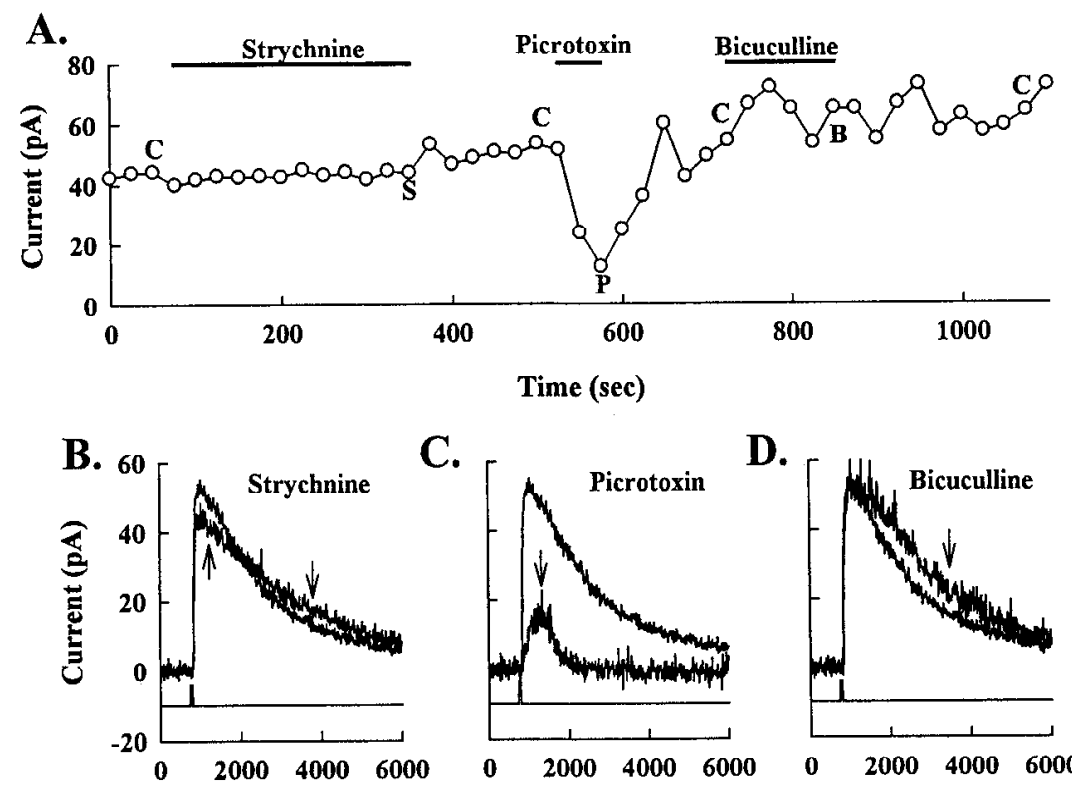

C.

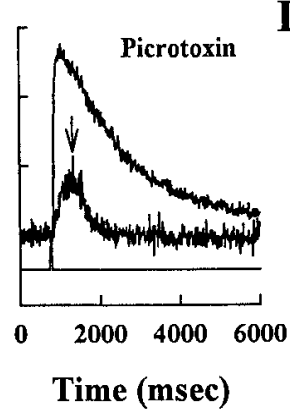

D.

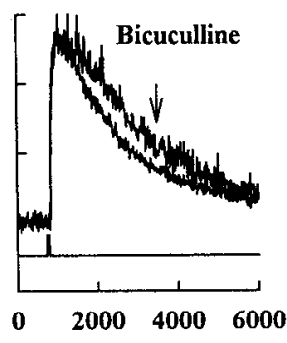

Figure 3. Bipolar cell GABA response is insensitive to bicuculline and strychnine. $A$, Peak current responses to puffs of $1 \mathrm{~mm}$ GABA at the bipolar cell terminals when the cell was clamped to $-10 \mathrm{mV}$. Strychnine $(0.5 \mu \mathrm{M})$ reduced the amplitude of the GABA response slightly, but bicuculline $(100 \mu \mathrm{M})$ did not reduce the amplitude of the GABA response. A short application of picrotoxin $(100 \mu \mathrm{M})$ reversibly reduced the amplitude of the response. Control responses in $B-D$ are the average of the four responses labeled $C$ in $A$. The responses recorded in the presence of the antagonists are indicated by arrows. $B$. Strychnine reduced the peak GABA response and slowed the decay of the response. The GABA response recorded in the presence of strychnine is labeled $S$ in $A$. $C$, Picrotoxin greatly reduced the amplitude of the peak GABA response. The GABA response recorded in the presence of picrotoxin is labeled $P$ in $A . D$, Bicuculline did not reduce the amplitude of the GABA response, but slowed the decay of the response. The GABA response recorded in the presence of bicuculline is labeled $B$ in $A$. The recording electrode contained the CsF intracellular solution. The reversal for the GABA current, in this and all subsequent figures, calculated using the Goldman-Hodgkin-Katz equation, was -72 mV, assuming a $P_{\mathrm{Cl}} / P_{\mathrm{F}}$ of 0.02 (Hille, 1992).

bipolar terminal GABA currents. Picrotoxin, a noncompetitive $\mathrm{GABA}_{\mathrm{A}}$ receptor antagonist, reduced the amplitude of the responses to GABA puffed at the bipolar terminal. Figure $2 B$ shows a series of current-voltage relationships constructed from the peak current responses to puffs of $1 \mathrm{~mm}$ GABA before and during the application of different concentrations of picrotoxin. Increasing concentrations of picrotoxin were sequentially applied to the bath, resulting in a reduction of the GABA current response. Larger doses caused a greater blockade of the GABA response. The $\mathrm{IC}_{50}$ (the $50 \%$ blocking concentration) for picrotoxin was between 1 and $10 \mu_{\mathrm{M}}$ at -100 and $-80 \mathrm{mV}$. Recovery of the GABA responses occurred after the application of $100 \mu \mathrm{M}$ picrotoxin (data not shown). The GABA response was reduced by picrotoxin in a dose-dependent manner over the full range of holding potentials. Increasing doses of picrotoxin reduced the slopes of the current-voltage relations. However, picrotoxin did not alter the shape of the current-voltage relations. This indicates that picrotoxin blocked the GABA responses in a voltage-independent manner. These data are similar to the results reported by Newland and Cull-Candy (1992) in dissociated rat sympathetic neurons.

Surprisingly, bicuculline, the classic $\mathrm{GABA}_{\mathrm{A}}$ receptor competitive antagonist, was relatively ineffective in blocking the response to GABA puffed at most bipolar terminals (see below). The pharmacology of the bipolar terminal GABA current responses is summarized in Figure 3. In this cell, we compared the ability of bicuculline, picrotoxin, or strychnine to block bipolar terminal GABA responses. The peak amplitudes of responses to puffs of $1 \mathrm{~mm}$ GABA, measured when the cell was held at $-10 \mathrm{mV}$, are shown in Figure $3 A$. The calculated reversal for the GABA currents was $-72 \mathrm{mV}$ for this and all subsequent figures (see caption). The competitive glycine receptor antagonist strychnine $(0.5 \mu \mathrm{M})$ was relatively ineffective, reducing the amplitude of the GABA current response only slightly. A brief application of $100 \mu \mathrm{M}$ picrotoxin significantly reduced the amplitude of the response to GABA and this reduction was reversible. By contrast, a longer exposure to $100 \mu \mathrm{M}$ bicuculline was ineffective in blocking the GABA current responses. Individual responses recorded in the presence of each antagonist are compared with a control response in Figure $3 B-D$. The control response in each panel is the average of all the pre- and postdrug treatment responses labeled " $C$ " in Figure $3 A$. Figure $3 B$ shows that strychnine minimally reduced the peak amplitude of the response and slowed the decay of the response (indicated by the arrows). Figure $3 C$ shows that picrotoxin greatly reduced the response amplitude and increased the rate of decay of the response (indicated by the arrow). Figure $3 \mathrm{D}$ shows that bicuculline did not reduce the peak amplitude of the response and, like strychnine, slowed the decay of the response (indicatcd by the arrow). The potent competitive $\mathrm{GABA}_{\mathrm{A}}$ antagonist SR95531 was also relatively ineffective in blocking bipolar GABA agonist responses (see below). In four bipolar cells the GABA responses were reduced $12 \pm 12 \%( \pm \mathrm{SD})$ by $100 \mu \mathrm{M}$ bicuculline, while in three additional bipolar cells, GABA responses were not reduced at all by $5 \mu \mathrm{M}$ SR 95331 . 

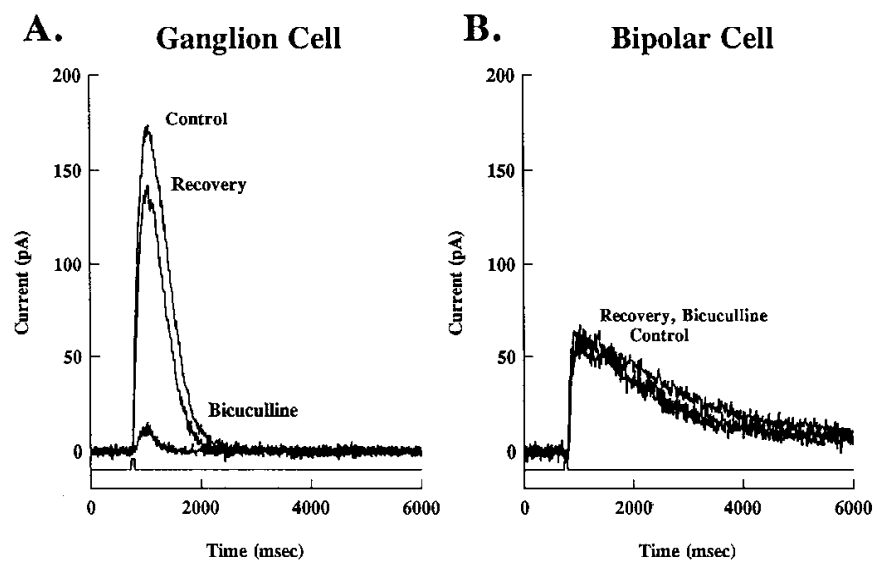

Figure 4. GABA current responses are pharmacologically distinct in ganglion cells and in bipolar cells. $A$, Responses to $1 \mathrm{~mm}$ GABA puffed at ganglion cell dendrites. The ganglion cell response is reduced by 100 $\mu \mathrm{M}$ bicuculline. Recovery occurs upon washout of the bicuculline. The ganglion cell was held at $-10 \mathrm{mV}$. $B$, The amplitude of the bipolar GABA current response was not reduced by bicuculline. The control, bicuculline, and recovery responses were almost identical. Bicuculline did, however, slow the decay of the GABA response. The bipolar cell was held at $-10 \mathrm{mV}$. The recording electrodes contained the CsF intracellular solution.

\section{Effects of GABA antagonists on ganglion cells}

To confirm that bicuculline and SR95531 were effective in the slice, we tested their effects on GABA responses recorded from ganglion cells. Figure 4 compares the antagonistic effects of bicuculline on ganglion cells and on bipolar cells. GABA evokes a current that reverses near $E_{\mathrm{C}}$ in both tiger salamander ganglion cells (Lukasiewicz and Werblin, 1990) and bipolar cells. Current responses to puffs of $1 \mathrm{~mm}$ GABA onto the ganglion cell dendrites that were recorded when the cell was voltage clamped to $-10 \mathrm{mV}$ are shown in Figure $4 A$. Bicuculline $(100 \mu \mathrm{M})$ almost completely blocked the GABA current response in ganglion cells. The GABA response recovered after the bicuculline was washed out. This is the same concentration of bicuculline that did not reduce the amplitude of the $\mathrm{G} \Lambda \mathrm{B} \Lambda$ current recorded in most bipolar cells (Fig. 4B). The amplitude of the bipolar cell GABA current recorded in the presence of bicuculline was identical to the amplitudes of the control and the recovery currents. Bicuculline slightly decreased the rate of decay of the GABA current in this bipolar cell. In three ganglion cells, bicuculline $(100 \mu \mathrm{M})$ reduced the amplitude of the GABA puff responses on average by $85 \perp 8 \%(\perp \mathrm{SD})$. The more potent $\mathrm{GABA}_{\mathrm{A}}$ antagonist SR95331 $(5 \mu \mathrm{M})$ reduced ganglion cell GABA puff responses on average by $87+8 \%(+\mathrm{SD} ; n=2)$. Similar results with bicuculline have been reported with ganglion cells in goldfish (Ishida and Cohen, 1988; Cohen et al., 1989). These results reinforce the notion that ganglion cells have $\mathrm{GABA}_{\mathrm{A}}$ receptors whereas bipolar cells have a GABA receptor that is pharmacologically distinct.

\section{Effects of muscimol on ganglion and bipolar cells}

The specific $\mathrm{GABA}_{\mathrm{A}}$ agonist muscimol evoked responses when puffed onto ganglion cell dendrites and the muscimol current response was reduced by the competitive $\mathrm{GABA}_{\mathrm{A}}$ antagonists in a reversible manner. Figure $5 B$ shows a plot of the peak muscimol $(1 \mathrm{~mm})$ currents recorded from a ganglion cell that was held at $-20 \mathrm{mV}$. Both bicuculline $(100 \mu \mathrm{M})$ and SR95531
( $5 \mu \mathrm{M})$ reduced the ganglion cell muscimol currents. In fact, 5 $\mu \mathrm{M}$ SR95531 was as effective as $100 \mu \mathrm{M}$ bicuculline in antagonizing the GABA or the muscimol responses in ganglion cells. In seven ganglion cells, SR95531 reduced the muscimol responses on average by $87 \pm 9 \%$. In one ganglion cell, where 5 $\mu \mathrm{M}$ SR95531 reduced the muscimol response by $83 \%, 100 \mu \mathrm{M}$ bicuculline reduced the response by $71 \%$.

The $\mathrm{GABA}_{\mathrm{A}}$ receptor agonist muscimol also evoked responses when puffed onto bipolar cell terminals, but the competitive $\mathrm{GABA}_{\mathrm{A}}$ antagonists were less effective at reducing these muscimol-elicited responses than those recorded in ganglion cells. Figure $5 A$ shows a plot of the peak current response amplitudes to $1 \mathrm{~mm}$ muscimol puffed at the bipolar terminal. The bipolar cell was voltage clamped to $0 \mathrm{mV}$ in this experiment. The potent $\mathrm{GABA}_{\mathrm{A}}$ antagonist SR95531, at $5 \mu \mathrm{M}$ (first application) and at $20 \mu \mathrm{M}$ (second application), did not reduce the amplitude of the muscimol response. Picrotoxin $(100 \mu \mathrm{M})$, however, did reduce the amplitude of the muscimol response. In five bipolar cells, SR95331 reduced the amplitude of the muscimol response by $21 \pm 15 \%( \pm \mathrm{SD})$. In one bipolar cell, where $5 \mu \mathrm{M}$ SR95531 reduced the amplitude of the muscimol response by $9 \%, 100$ $\mu \mathrm{M}$ bicuculline did not reduce the response at all. Muscimol activated GABA receptors on bipolar cells, but these responses were not blocked by the competitive $\mathrm{GABA}_{\mathrm{A}}$ antagonists. This suggests that muscimol acts at $\mathrm{GABA}_{C}$ receptors on bipolar terminals. Nistri and Sivilotti (1985) reported that muscimol was as effective as $\mathrm{GABA}$ at $\mathrm{GABA}_{\mathrm{C}}$ receptors in the frog tectum (but see Qian and Dowling, 1993). In tiger salamander bipolar cells, the amplitudes of the muscimol responses $(79 \pm 29 \mathrm{pA}$, $\pm \mathrm{SD} ; n=6 ; 1 \mathrm{mM}$ ) were on average $66 \%$ of the amplitude of the GABA responses $(120 \pm 44 \mathrm{pA}, \pm \mathrm{SD} ; n=7 ; 1 \mathrm{~mm})$.

\section{Differential effects of pentobarbital on bipolar cells versus ganglion cells}

Pentobarbital enhances responses mediated by $\mathrm{GABA}_{\mathrm{A}}$ receptors in the vertebrate CNS (Nicoll, 1972; Ransom and Barker, 1976; Macdonald and Barker, 1979; Macdonald et al., 1989). The effects of pentobarbital on GABA currents in bipolar cells were examined and pentobarbital $(100-1000 \mu \mathrm{M})$ did not significantly increase the amplitude of GABA puff responses in all bipolar cells that were tested. We have found, however, that in some barbiturate-sensitive cells, pentobarbital increases the duration of the response without significantly increasing its peak amplitude. Therefore, we integrated the current responses to determine the charge transfer elicited by GABA in order to verify whether or not pentobarbital was effective in spite of no change in the peak amplitude of the response.

Figure $6 A$ shows the effect of $100 \mu \mathrm{M}$ pentobarbital on the charge transfer elicited by puffs of $100 \mu \mathrm{M}$ GABA onto bipolar cell terminals when the cell was held at $0 \mathrm{mV}$. Pentobarbital did not enhance the charge transfer elicited by GABA. To ensure that the perfusion system was working properly, picrotoxin was applied either before or after the pentobarbital treatment. Picrotoxin always reduced the amount of the GABA-elicited charge transfer, confirming that the perfusion system was functional Figure $6 B$ compares current records of GABA responses recorded before, during, and after the application of pentobarbital. Neither the amplitude nor the duration of the bipolar GABA currents was enhanced by pentobarbital. Similar results were obtained when $100 \mu \mathrm{M}$ GABA $(n=7)$ or $1 \mathrm{~mm} \mathrm{GABA}(n=7)$ was putted onto bipolar terminals. In most bipolar cells ( 10 of 14), pentobarbital did not enhance the integrated current re- 


\section{Muscimol}

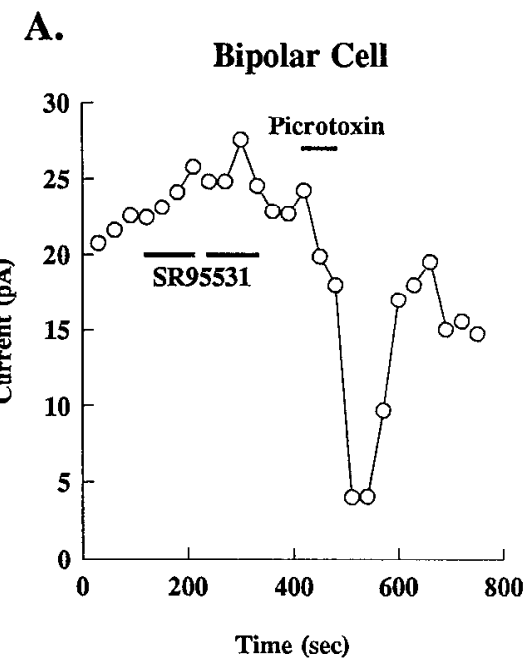

B.

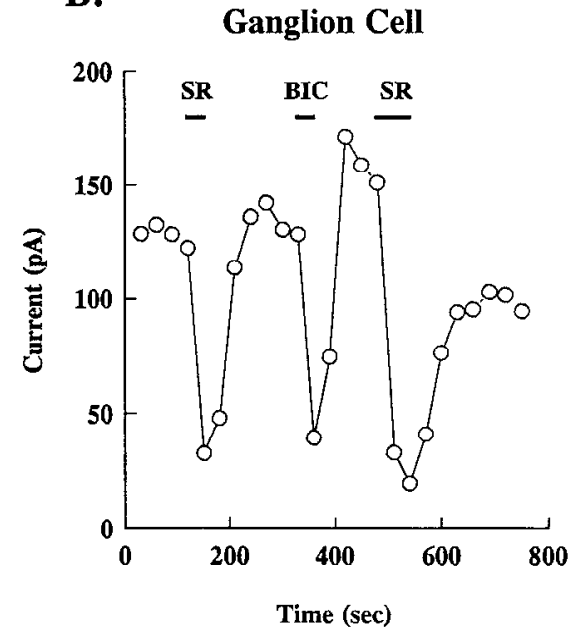

Figure 5. Muscimol current responses recorded in bipolar and ganglion cells were differentially sensitive to SR 95331 . $A$, A series of peak responses to puffs of $1 \mathrm{~mm}$ muscimol at the bipolar terminals plotted versus time. Applications of SR 95531 at $5 \mu \mathrm{M}$ (first application) and at $20 \mu \mathrm{M}$ (second application) did not reduce the response amplitude. Picrotoxin $(100 \mu \mathrm{M})$ reversibly reduced the amplitude of the muscimol response. The bipolar cell was held at 0 $\mathrm{mV} . B$, Peak responses to $1 \mathrm{~mm}$ muscimol puffed at a ganglion cell's dendrites. SR95531 (SR;5 $\mu \mathrm{M})$ reversibly reduced muscimol responses. Bicuculline $(B I C ; 100 \mu \mathbf{M})$ was about as potent as $5 \mu \mathrm{M} \mathrm{SR} 95531$ in reducing both muscimol and GABA responses in ganglion cells. The ganglion cell was held at -20 $\mathrm{mV}$. The recording electrodes containcd the CsF intracellular solution. sponses to GABA puffed at the bipolar terminal. However, in four cells, the GABA charge transfer was slightly increased by $100 \mu \mathrm{M}$ pentobarbital $(129 \pm 12 \%, \pm \mathrm{SD}$, of control; $n=2,1$ mM GABA; $n=2,100 \mu \mathrm{M}$ GABA).

In contrast to its effect on bipolar cells, pentobarbital significantly enhanced the GABA responses recorded in ganglion cells. Figure $6 C$ shows the effects of pentobarbital on charge transfer elicited by GABA puffs (100 $\mu \mathrm{M})$ onto ganglion cell dendrites. In this experiment, the ganglion cell was voltage clamped to
$-10 \mathrm{mV}$. When $100 \mu \mathrm{M}$ pentobarbital was present in the bath, the GABA charge transfer was increased approximately fourfold. The GABA response rapidly returned to control levels when pentobarbital was washed out. GABA current responses recorded in the presence and absence of pentobarbital are shown in Figure $6 \mathrm{D}$. Pentobarbital increased both the amplitude and the duration of the ganglion cell GABA current responses. Pentobarbital $(100 \mu \mathrm{M})$ enhanced the responses to puffs of $1 \mathrm{~mm}$ GABA on average to $231 \%$ of control $( \pm 75 \% \mathrm{SD}, n=5)$ and

\section{Bipolar Cell}
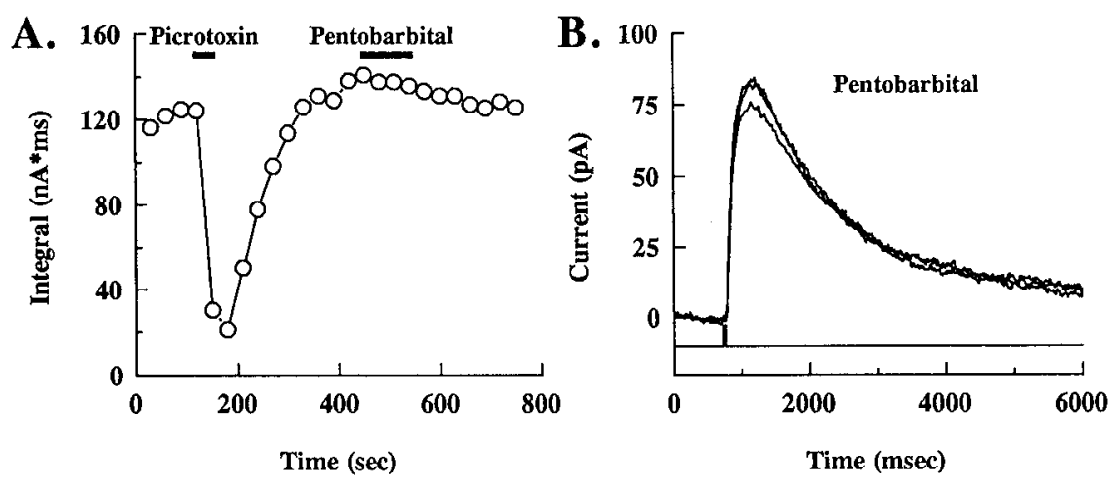

Ganglion Cell
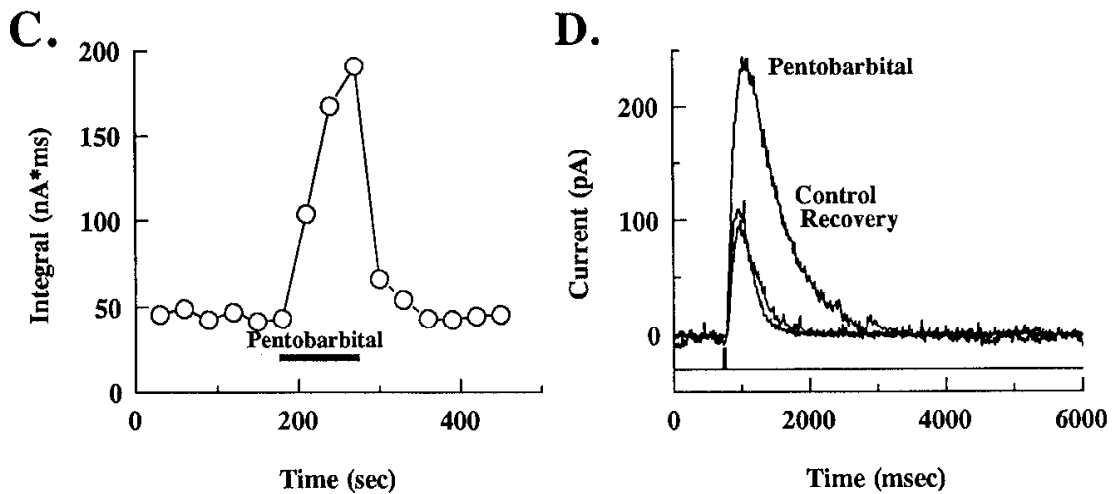

Figure 6. Pentobarbital enhances GABA responses in ganglion cells, but not in bipolar cells. $A$, Charge transfer (integrated current responses) by GABA puffed at bipolar terminals. Pentobarbital did not effect the charge transfer elicited by GABA. Picrotoxin did reduce the GABA-evoked charge transfer and served as a control to confirm that the perfusion system was working properly. Similar results were obtained when pentobarbital was applied before picrotoxin treatment. $B$, Individual current records recorded before, during, and after pentobarbital application. Pentobarbital did not increase the amplitude or the duration of the GABA current response. $C$, Charge transfer in response to GABA puffed at ganglion cell dendrites was enhanced by $100 \mu \mathrm{M}$ pentobarbital in a reversible manner. $D$, Individual current responses recorded before, during, and after pentobarbital application. Both the amplitude and the duration of the GABA response were enhanced by pentobarbital. The bipolar cell was held at $0 \mathrm{mV}$ and the ganglion cell was held at $-10 \mathrm{mV}$. The recording electrodes contained the $\mathrm{CsF}$ intracellular solution. 


\section{Bipolar Cell}
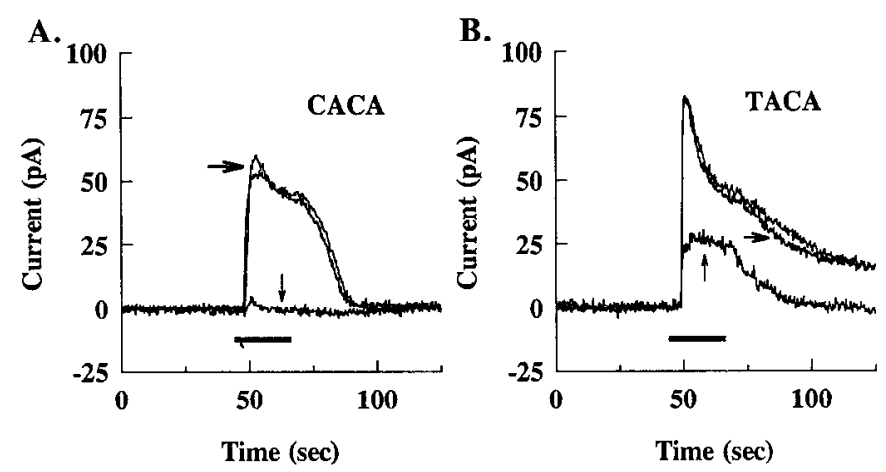

Figure 7. Bipolar cell CACA and TACA currents are sensitive to picrotoxin, but not bicuculline. $A$, Current responses to bath application of $250 \mu \mathrm{M}$ CACA. Antagonists were bath applied for $45 \mathrm{sec}$ prior to, and during, the agonist application. Bicuculline did not reduce the amplitude of the CACA response. Picrotoxin reduced the CACA current almost completely. The control response is the average of the responses before and after antagonist application in both $A$ and $B$. $B$, Current responses to bath application of $250 \mu \mathrm{M}$ TACA. Bicuculline did not significantly reduce the peak response, but did slightly reduce the plateau of the response. Picrotoxin markedly reduced the TACA currents. The horizontal arrows indicatc the current responses recorded in the presence of bicuculline. The vertical arrows indicate the current responses recorded in the presence of picrotoxin. The duration of the agonist bath applications is indicated by the bar below the current traces. The cell was held at $0 \mathrm{mV}$. Responses in $A$ and $B$ were from the same cell. The recording electrodes contained the CsF intracellular solution.

enhanced the responses to $100 \mu \mathrm{M}$ GABA on average to $445 \%$ of control $( \pm 227 \% \mathrm{SD}, n=7)$.

\section{Effects of cis- and trans-aminocrotonic acid on bipolar and ganglion cells}

Recent studies have shown that the GABA agonist CACA is effective at $\mathrm{GABA}_{C}$ receptors (Sivilotti and Nistri, 1989; Feigenspan et al., 1993; Qian and Dowling, 1993), although it is less effective than GABA. TACA has been reported to be more effective than CACA at GABA . receptors (Sivilotti and Nistri, 1989; Feigenspan et al., 1993). The actions of the isomeric GABA agonists CACA and TACA on bipolar and ganglion cells were determined after synaptic transmission was blocked with $20 \mathrm{mM}$ $\mathrm{MgCl}_{2}$. Bath application of the agonists revealed that GABA was more effective than either IACA or CACA at both bipolar and ganglion cells. When all three agonists were applied to bipolar cells, TACA $(250 \mu \mathrm{M})$ currents were found to be $88 \pm 6 \%$ $( \pm \mathrm{SD} ; n=5)$ of the GABA $(250 \mu \mathrm{M})$ current amplitude and CACA $(250 \mu \mathrm{M})$ currents were found to be $52 \pm 8 \%( \pm \mathrm{SD} ; n$ $=5$ ) of the GABA current amplitude. A similar rank order of effectiveness was found for the three agonists in ganglion cells. However, CACA was less effective than GABA in ganglion cells compared to bipolar cells. Ganglion cell TACA currents were $89 \pm 12 \%( \pm \mathrm{SD} ; n=3)$ of the GABA current amplitude and ganglion cell CACA currents were $33 \pm 10 \%( \pm \mathrm{SD} ; n=3)$ of the GABA current amplitude.

For bipolar cells, the pharmacology of the CACA and TACA responses was similar to that described for GABA and muscimol. Figure $7 A$ shows that the CACA response recorded from a bipolar cell was almost completely blocked by $100 \mu \mathrm{M}$ picrotoxin. The bipolar cell was held at $0 \mathrm{mV}$. In four cells, picrotoxin reduced the amplitude of the CACA $(250 \mu \mathrm{M})$ responses

\section{Ganglion Cell}

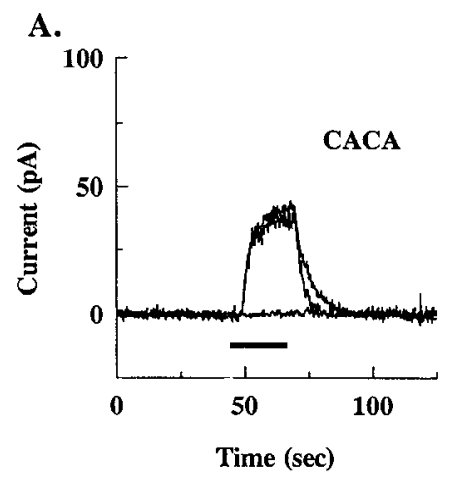

B.

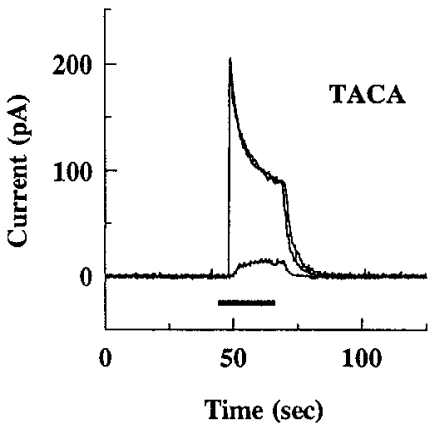

Figure 8. Ganglion cell CACA and TACA currents are potently reduced by bicuculline. $A$, Current responses to bath application of 250 $\mu \mathrm{M}$ CACA. Antagonists were bath applied for $45 \mathrm{sec}$ prior to and during the agonist application. Bicuculline completely and reversibly blocked the CACA response. The amplitude of the recovery response was slightly smaller than the control. $B$, Current responses to bath application of $250 \mu \mathrm{M}$ TACA. Bicuculline significantly reduced the TACA response. The TACA response recovered fully upon washout of bicuculline. The duration of the agonist bath applications is indicated by the bar the current traces. The cell was held at $0 \mathrm{mV}$. Responses in $A$ and $B$ were from the same cell. The recording electrodes contained the CsF intracellular solution.

on average by $90 \pm 2 \%( \pm \mathrm{SD})$. By contrast, Figure $7 \mathrm{~A}$ also shows that $100 \mu \mathrm{M}$ bicuculline was ineffective in reducing the amplitude of the CACA response. In the four bipolar cells tested, $100 \mu \mathrm{M}$ bicuculline reduced the CACA $(250 \mu \mathrm{M})$ responses by only $3 \pm 4 \%( \pm$ SD). Similarly, SR95531 $(5 \mu \mathrm{M})$ was also ineffective; SR 95531 reduced the CACA responses by $6 \pm 6 \%( \pm S D$; $n=3$ ). TACA responses recorded in bipolar cells were also reduced by picrotoxin as illustrated in Figure $7 B$. Picrotoxin reduced the amplitude of the TACA response in this cell by $64 \%$. Picrotoxin was slightly less effective in reducing TACA responses compared to CACA responses. Picrotoxin $(100 \mu \mathrm{M})$ reduced the amplitude of the bipolar cell TACA $(250 \mu \mathrm{M})$ responses on average by $79 \pm 8 \%( \pm \mathrm{SD} ; n=4)$. Figure $7 B$ also shows that bicuculline reduced the amplitude of the TACA response minimally. Bicuculline was slightly more effective in reducing TACA responses compared to CACA responses. $\mathrm{Bi}$ cuculline $(100 \mu \mathrm{M})$ reduced the amplitude of the bipolar cell TACA $(250 \mu \mathrm{M})$ responses by $28 \pm 19 \%( \pm \mathrm{SD})$. Similarly, SR95531 $(5 \mu \mathrm{M})$ was also relatively ineffective; TACA responses were reduced by SR 95531 by $24 \pm 9 \%( \pm \mathrm{SD} ; n=3)$.

Ganglion cell TACA and CACA responses were pharmacologically distinct from those recorded in bipolar cells. Figure $8 A$ shows a ganglion cell response to CACA when it was voltage clamped to $0 \mathrm{mV}$. In contrast to the bipolar cell responses, bicuculline completely blocked the CACA-elicited current in this cell. The current response recovered after bicuculline was washed out. In four ganglion cells tested, $100 \mu \mathrm{m}$ bicuculline reduced the responses to CACA $(250 \mu \mathrm{M})$ on average by 96.5 $\pm 2.7 \%( \pm \mathrm{SD} ; n=4)$. TACA responses were also effectively reduced by bicuculline as illustrated in Figure $8 B$. The TACA response of this cell was reduced by $87 \%$ by bicuculline. The TACA response completely recovered after bicuculline was washed out. In this cell, the peak TACA response was approximately 4.5 times larger than its peak CACA response (Fig. $8 A$ ). In four ganglion cells tested, $100 \mu \mathrm{M}$ bicuculline reduced the responses to TACA $(250 \mu \mathrm{M})$ on average by $88 \pm 3 \%( \pm \mathrm{SD})$. 
These data are consistent with the presence of $\mathrm{GABA}_{\mathrm{A}}$ receptors on ganglion cells and support the presence of a pharmacologically distinct GABA receptor on bipolar cells.

\section{$A$ mixture of $G A B A_{A}$ and $G A B A_{C}$ receptors on bipolar cells}

Some bipolar cells did have a $\mathrm{GABA}_{\mathrm{A}}$ component to their current responses. For these cells the $\mathrm{GABA}_{\mathrm{A}}$ antagonists bicuculline and SR95531 did block a significant component of the GABA current response. In two cells, bicuculline or SR95531 reduced the $\mathrm{G} \Lambda \mathrm{B} \Lambda$ puff response by more than $60 \%$. However, the majority of cells ( 11 of 13 ) were relatively resistant to blockade by these competitive $\mathrm{GABA}_{\mathrm{A}}$ antagonists. This indicates that there may be a continuum in the complement of GABA receptors on bipolar cells. Most bipolar cells (8 of 13) seem to have a predominance of $\mathrm{GABA}_{C}$ receptors $(<25 \%$ reduction by competitive $\mathrm{GABA}_{\mathrm{A}}$ antagonists), some (3 of 13) seem to have a mix of $\mathrm{GABA}_{C}$ and $\mathrm{GABA}_{\mathrm{A}}$ receptors $(>25 \%$ and $<50 \%$ reduction), and few ( 2 of 13) seem to have a predominance of $\mathrm{GABA}_{\mathrm{A}}$ receptors $(>50 \%$ reduction).

Also, as described above, pentobarbital slightly enhanced GABA responses in a minority of bipolar cells (4 of 14). The mean enhancement of pentobarbital for puffs of $100 \mu \mathrm{M}$ GABA onto bipolar cell terminals was significantly less than the enhancement found for puffs of $100 \mu \mathrm{M}$ GABA onto ganglion cell dendrites ( $129 \%$ vs $445 \%$ of control responses). The small effect of pentobarbital on some bipolar cells also suggests that a component of their GABA responses may be mediated by $\mathrm{GABA}_{\mathrm{A}}$ receptors.

Further support for the presence of $\mathrm{GABA}_{\mathrm{A}}$ receptors on some bipolar terminals comes from the findings that in some cells the responses to IACA were partially blocked by either bicuculline or SR95531. TACA has been shown to be a better agonist at

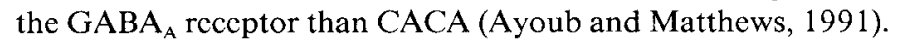
In seven cells, the TACA response was reduced $0-47 \%$ by bicuculline or SR95531. In contrast, these competitive antagonists were less effective in reducing the CACA responses, causing only a $0-14 \%$ reduction $(n=7)$. This suggests that CACA may be acting preferentially at $\mathrm{GABA}_{C}$ receptors. Moreover, these antagonists were always much more effective in reducing the amplitude of CACA and TACA responses in ganglion cells. This is consistent with the notion that ganglion cell responses are largely mediated by $\mathrm{GABA}_{\mathrm{A}}$ receptors and that some bipolar cell responses are mediated by a mixture of both $\mathrm{GABA}_{C}$ and $\mathrm{GABA}_{\mathrm{A}}$ receptors. Similarly, Feigenspan et al. (1993) presented evidence that rat amacrine cells possessed primarily $\mathrm{GABA}_{\mathrm{A}}$ receptors and that rat bipolar cells possessed both $G A B A_{A}$ and $\mathrm{GABA}_{\mathrm{C}}$ receptors.

\section{Pharmacology does not correlate with bipolar cell morphology}

We were able to identify 17 of 24 bipolar cells by their characteristic morphologies (Hare et al., 1986) by including Lucifer yellow in the recording pipette. Thirteen cells were identified as ON bipolar cells and four cells were identified as OFF bipolar cells. No significant difference in antagonist sensitivity was found between ON and OFF bipolar cells.

\section{Discussion}

A $G A B A_{C}$ receptor on tiger salamander bipolar cell terminals A population of $\mathrm{GABA}$ receptors on bipolar cells was found to gate chloride channels, but they did not have the typical $\mathrm{GABA}_{\mathrm{A}}$ receptor pharmacology. They were sensitive to the noncompetitive antagonist picrotoxin, but relatively insensitive to the competitive $\mathrm{GABA}_{\mathrm{A}}$ receptor antagonists bicucullinc and SR95531. Also, pentobarbital, a barbiturate that enhances GA$B A_{A}$ responses, was relatively ineffective in augmenting the GABA-mediated responses in bipolar cells. To ensure that the applied drugs were active in the slice, we tested the effects of these substances on GABA receptors on ganglion cell dendrites. Using the same methodologies and concentrations of drugs, we found that the GABA receptors on ganglion cells, in contrast to those on bipolar cells, appeared to be of the conventional GA$\mathrm{BA}_{\mathrm{A}}$ subtype. The receptors on ganglion cells were very sensitive to blockade by both bicuculline and SR95531, as well as picrotoxin. In addition, the current responses mediated by these receptors were enhanced by pentobarbital. Ganglion cells isolated from the goldfish retina also possess conventional $\mathrm{GABA}_{\mathrm{A}}$ receptors and have a similar pharmacology (Ishida and Cohen, 1988; Cohen et al., 1989).

\section{$G A B A_{C}$ receptors in other species}

GABA responses that were bicuculline insensitive but picrotoxin sensitive have been reported in frog tectal neurons (Nistri and Sivilotti, 1985; Sivilotti and Nistri, 1989). Excitatory field potentials in the tectum were found to be enhanced by either GABA or muscimol. TACA, an extended analog of GABA, was equipotent to GABA, while the $c$ is isomer (CACA), a folded analog of GABA, was less potent. Picrotoxin, but not bicuculline, blocked the actions of all GABA agonists.

Recently, evidence has been presented that GABA receptors on rod horizontal cells in the white perch (Qian and Dowling, 1993) and on bipolar cells in the rat (Feigenspan et al., 1993) have a $\mathrm{GABA}_{C}$ pharmacology. GABA receptors in these preparations were resistant to bicuculline blockade and to barbiturate enhancement. However, the GABA receptors on rat bipolar cells described by Feigenspan et al. (1993) did not behave entirely like other $\mathrm{GABA}_{C}$ receptors described. In contrast to our findings, and those of Qian and Dowling (1993), the rat bipolar cell GABA currents were resistant to the noncompetitive GABA antagonist picrotoxinin. Picrotoxinin is the toxic component of picrotoxin (Budavari, 1989), whereas picrotoxin is a mixture of $1 \mathrm{~mol}$ of picrotoxinin and $1 \mathrm{~mol}$ of picrotin. It is unclear what the explanation is for this picrotoxin/picrotoxinin discrepancy. It may be that the subunit composition of the $\mathrm{GABA}_{\mathrm{C}}$ receptors on rat bipolar cells differ from those in fish and amphibia, thus accounting for the differential picrotoxin sensitivity (see below) (Cutting et al., 1993). Recent work has shown that in Drosophila, a point mutation in the region thought to encode for the chloride channel can confer picrotoxinin resistance to the normally picrotoxinin-sensitive GABA receptor (ffrench-Constant et al., 1993). Further work on mammalian bipolar cells is needed to determine whether their $\mathrm{GABA}_{c}$ receptors are pharmacologically and/or molecularly distinct. The GABA antagonist pharmacology reported here for tiger salamander bipolar cells is more similar to that reported in frog tectal neurons and white perch rod horizontal cells than that reported in rat bipolar cells.

In salamander and fish retina, both $\mathrm{GABA}_{\mathrm{A}}$ and $\mathrm{GABA}_{C}$ receptors are sensitive to picrotoxin antagonism (Qian and Dowling, 1993; Lukasicwicz and Werblin, 1994). Physiological studies suggest that picrotoxin acts as a noncompetitive antagonist (Constanti and Nistri, 1976; Newland and Cull-Candy, 1992). Binding studies indicate that picrotoxin binds to a site that is either on or closely associated with the chloride channel portion of the $\mathrm{GABA}_{\mathrm{A}}$ receptor, but distinct from the GABA recognition site (Enna et al., 1977). The similar picrotoxin sensitivities of 
the $\mathrm{GABA}_{\mathrm{C}}$ and $\mathrm{GABA}_{\mathrm{A}}$ receptors suggest their structures are similar with regard to the picrotoxin binding site. The competitive $\mathrm{CABA}_{\mathrm{A}}$ antagonist bicuculline is thought to act at the GABA recognition site (Curtis et al., 1970). A more effective competitive antagonist that also acts at the recognition site is SR95531 (Heaulme et al., 1986; Wermuth et al., 1987). The relative insensitivity of the $\mathrm{GABA}_{C}$ receptor to these competitive antagonists indicates that the $G A B A$ recognition sites are different on $\mathrm{GABA}_{C}$ and $\mathrm{GABA}_{\mathrm{A}}$ receptors. Barbiturates are thought to enhance GABA responses by binding to an allosteric site either on or associated with the channel (Macdonald et al., 1986). We found that barbiturates were relatively ineffective in enhancing $\mathrm{GABA}_{C}$ receptor-mediated responses in tiger salamander bipolar cells. This suggests that the barbiturate binding site found on $\mathrm{GABA}_{\mathrm{A}}$ receptors is probably not present (or has a markedly lower affinity) on $\mathrm{GABA}_{C}$ receptors.

CACA has been reported by others (Sivilotti and Nistri, 1989; Feigenspan et al., 1993; Qian and Dowling, 1993) to be less effective than GABA at the $\mathrm{GABA}_{c}$ receptor. We also found that CACA was less effective than GABA not only at the bipolar terminals, but at the ganglion cell dendrites as well. However, CACA was more effective on bipolar cells (responses were $52 \%$ of GABA control responses) than on ganglion cells (responses were $33 \%$ of GABA control responses), indicating that CACA was more effective at $\mathrm{GABA}_{C}$ receptors in our preparation. We found TACA to be more effective than CACA at the bipolar terminals. This is in agreement with Sivilotti and Nistri (1989) and Feigenspan et al. (1993), who also found that TACA was more effective than $\mathrm{CACA}$ at $\mathrm{GABA}_{C}$ receptors. Qian and Dowling (1993) reported that muscimol elicited a smaller maximal response but was more potent than GABA in white perch rod horizontal cells. On the other hand, Nistri and Sivilotti (1985) found that muscimol was as efficacious as but more potent than $\mathrm{GABA}$ in the frog tectum. In tiger salamander bipolar cells, the amplitudes of the muscimol responses were on average $66 \%$ of the amplitude of the GABA responses.

\section{$G A B A$ sensitivity highest at bipolar terminals}

We found that the terminals of tiger salamander bipolar cells were much more sensitive to GABA than their somas or dendrites. Since there is considerable evidence for GABAergic horizontal cells in salamander (Pourcho et al., 1984; Mosinger et al., 1986; Wu, 1986; Yang and Yazulla, 1988; Yang et al., 1992), our results suggest that horizontal cells feed back to photoreceptors and do not significantly feed forward to bipolar cells. Evidence from turtle (Baylor et al., 1971), fish (Burkhardt, 1977; Murakami et al., 1982), and salamander (Attwell et al., 1983; Skrzypek and Werblin, 1983) favors horizontal cell feedback to photoreceptor terminals. However, we cannot rule out that tiger salamander bipolar cell dendrites have a relatively low sensitivity to GABA. Tachibana and Kaneko (1987) reported that goldfish bipolar dendrites had a low GABA sensitivity compared to the terminal region. A minor component of the surround input may be mediated by feedforward inputs to bipolar cells (Yang and $\mathrm{Wu}, 1991 ; \mathrm{Wu}, 1992$ ).

\section{Bipolar $G A B A$ receptors in other species}

In both goldfish and mouse, bipolar cells have been shown to be the most sensitive to GABA application at the synaptic terminal regions (Tachibana and Kaneko, 1987; Suzuki et al., 1990). Unlike those in salamander, these GABA responses appeared to be dominated by the conventional $\mathrm{GABA}_{\mathrm{A}}$ receptor type: they were sensitive to both bicuculline and pentobarbital. We found that only a minority of salamander bipolar cell terminals were sensitive to bicuculline and pentobarbital. Similarly, rat bipolar cell GABA responses are apparently mediated by both $\mathrm{GABA}_{\mathrm{A}}$ and $\mathrm{GABA}_{C}$ receptors (Feigenspan et al., 1993). This variety of results suggests that bipolar cells in different species may possess different complements of $\mathrm{GABA}_{\mathrm{A}}$ and $\mathrm{GABA}_{C}$ receptors.

\section{$A$ diversity of $G A B A$ receptors}

Recent molecular biology studies have shown that there is a large family of genes for the $\mathrm{GABA}_{\mathrm{A}}$ receptor subunits. Different $\mathrm{GABA}_{\mathrm{A}}$ receptor subtypes are thought to be composed of different combinations from different subunit classes. Four major classes of subunits have been identified in the rodent $\mathrm{CNS}$. These classes are called the $\alpha$-, the $\beta$-, the $\gamma$-, and the $\delta$-subunits (Wisden and Seeburg, 1992). The $\alpha$-subunits show the greatest diversity, and mutations of these subunits have been shown to alter the affinity for benzodiazepine binding (Pritchett and Seeburg, 1991; Weiland et al., 1992). The function of the $\beta$-subunits is not well understood, but these subunits have been shown to be essential for recombinant $\mathrm{GABA}_{\mathrm{A}}$ receptor expression (Wisden and Seeburg, 1992). The $\gamma$-subunits have been shown to be essential for conferring benzodiazepine sensitivity to the $\alpha \beta$ subunit complexes (Pritchett et al., 1989; Knoflach et al., 1991). The function of the $\delta$-subunit is unclear (Wisden and Seeburg, 1992).

A new GABA receptor subunit $(\rho 1)$ that is highly expressed in the retina has recently been cloned (Cutting et al., 1991). When the $\rho 1$-subunit was expressed in Xenopus oocytes, GABAmediated chloride current responses were recorded that could be blocked by picrotoxin, but not bicuculline (Shimada et al., 1992). This GABA current also was not enhanced by pentobarbital. Coexpression of the $\rho 1$-subunit with either the $\alpha 1$ - or $\beta 1$-subunits (both exhibit bicuculline sensitivity) did not modify the bicuculline or pentobarbital insensitivity. Similar results were obtained by Polenzani et al. (1991) when they expressed polyA' RNA isolated from mammalian retina in frog oocytes. In contrast, polyA + RNA isolated from mammalian cortex exhibited a conventional $\mathrm{GABA}_{\mathrm{A}}$ receptor pharmacology when expressed in frog oocytes. Recently, the properties of a newly characterized $\rho 2$ GABA receptor subunit have been described (Cutting et al., 1993). Expression in Xenopus oocytes has shown that the $\rho 2$-subunit, like the $\rho 1$-subunit, is insensitive to bicuculline and barbiturates. There were, however, differences between the $\rho 1$ and $\rho 2$ GABA currents. The $\rho 2$ GABA currents were smaller, more sustained, and less sensitive to picrotoxin blockade than the $\rho 1$ GABA currents. These differential picrotoxin sensitivities may explain, in part, the differences between our results and those of Fiegenspan et al. (1993), which were discussed above. Based on our results we would predict that in the tiger salamander the $\rho$-subunits would be expressed to a larger extent in bipolar cells than in ganglion cells. It is possible that other neurons in the tiger salamander retina may also possess this unique GABA receptor pharmacology. However, preliminary studies show that some amacrine cells are pharmacologically similar to ganglion cells; that is, they have bicuculline/SR 95531-sensitive GABA responses.

\section{References}

Attwell D, Werblin FS, Wilson M, Wu S (1983) A sign reversing pathway from rods to double and single cones in the retina of the tiger salamander. J Physiol (Lond) 336:313-333. 
Attwell D, Mobbs P, Tessicr-Lavignc M, Wilson M (1987) Neurotransmitter-induced currents in retinal bipolar cells of the axolotl, Ambystoma mexicanum. J Physiol (Lond) 387:125-161.

Ayoub GS, Matthews G (1991) Conformational specificity of GABA binding to the presynaptic GABA A $_{A}$ receptor. Neuroreport 2:809-811.

Barnes S, Werblin F (1986) Gated currents in amacrine cells. Proc Natl Acad Sci USA 83:1509-1512.

Barnes S, Werblin F (1987) Direct excitatory and lateral inhibitory synaptic inputs to amacrine cells in the tiger salamander retina. Brain Res 406:233-237.

Baylor DA, Fuortes MGF, O'Bryan PM (1971) Receptive fields of single cones in the retina of the turtle. J Physiol (Lond) 214:265-294.

Belgum JH, Dvorak DR, McReynolds JS (1984) Strychnine blocks transient but not sustained inhibition in mudpuppy retinal ganglion cells. J Physiol (Lond) 354:273-286.

Budavari S, ed (1989) Merck index. Rahway, NJ: Merck.

Burkhardt DA (1977) Responses and receptive-field organization of cones in perch retinas. J Neurophysiol 40:53-62.

Chun MH, Wässle H (1989) GABA-like immunoreactivity in the cat retina: electron microscopy. J Comp Neurol 279:55-67.

Cohen BN, Fain GL, Fain MJ (1989) GABA and glycine channels in isolate ganglion cells from the goldfish retina. J Physiol (Lond) 417: 53-82.

Constanti A, Nistri A (1976) A comparative study of the actions of GABA and piperazine on the lobster fibre and the frog spinal cord. Br J Pharmacol 57:347-358.

Curtis DR, Duggan AW, Felix D, Johnston GAR (1970) GABA, bicuculline and central inhibition. Nature 226:1222-1224.

Cutting GR, Lu L, O'Hara BF, Kasch LM, Montrose-Rafizadeh C, Donovan DM, Shimada S, Antonarkakis SE, Guggino WB, Uhl GR, Kazazian HH (1991) Cloning of the $\gamma$-aminobutyric acid (GABA) $\rho 1$ cDNA: a GABA receptor subunit highly expressed in the retina. Proc Natl Acad Sci USA 88:2673-2677.

Cutting GR, Wang T-L, Guggino WG (1993) Retina-specific GABA subunits rhol and rho2 expressed in Xenopus laevis oocytes for receptors with distinct pharmacological and physiological properties. Invest Ophthalmol Vis Sci 34:1380.

Dowling JE, Werblin FS (1969) Organization of the retina of the mudpuppy, Necturus maculosus. I. Synaptic structure. J Neurophysiol 32:315-338

Enna SJ, Collins JF, Snyder SH (1977) Stereospecificity and structureactivity requirements of GABA receptor binding in rat brain. Brain Res 124:185-190.

Famiglietti EV, Kolb H (1976) Structural basis for ON- and OFFcenter responses in retinal ganglion cells. Science 194:193-195.

Famiglietti EV, Kaneko A, Tachibana M (1977) Neuronal architecture of ON and OFF pathways to ganglion cells in carp retina. Science 198:1267-1269.

Feigenspan A, Wässle H, Bormann J (1993) Pharmacology of GABA receptor $\mathrm{Cl}^{-}$channels in rat retinal bipolar cells. Nature 361:159162.

french-Constant RH, Rocheleau TA, Steichen JC, Chalmers AE (1993) A point mutation in a Drosophila GABA receptor confers insecticide resistance. Nature 363:449-451

Hamill OP, Marty A, Neher E, Sakmann B, Sigworth FJ (1981) Improved patch-clamp techniques for high resolution current recording from cells and cell-free membrane patches. Pflucgers Arch 391:85100 .

Hare WA, Lowe JS, Owen WG (1986) Morphology of physiologically identified bipolar cells in the retina of the tiger salamander retina, Ambystoma tigrinum. J Comp Neurol 252:130-138.

Heaulme M, Chambron J-P, Leyris R, Molinard J-C, Wermuth CG, Biziere K (1986) Biochemical characterization of the interaction of three pyridazinyl-GABA derivatives with the GABA-A site. Brain Res 384:224-231.

Heidelberger R, Matthews G (1991) Inhibition of calcium influx and calcium current by $\gamma$-aminobutyric acid in single synaptic terminals. Proc Natl Acad Sci IJSA 887:135-139.

Hille B (1992) Ionic channels of excitable membranes. Sunderland, MA: Sinauer.

Hughes TE, Grunert U, Karten HJ (1991) $\mathrm{G} \wedge \mathrm{B} \Lambda_{\mathrm{A}}$ receptors in the retina of the cat: an immunohistochemical study of wholemounts, sections, and dissociated cells. Vis Neurosci 6:229-238.

Hurd LD II, Eldred WD (1989) Localization of GABA- and GADlike immunoreactivity in the turtle retina. Vis Neurosci 3:9-20.
Ishida AT, Cohen BN (1988) GABA-activated whole-cell currents in isolated retinal ganglion cells. J Neurophysiol 60:381-396.

Johnston GAR (1986) Multiplicity of GABA receptors. In: Benzodiazepine/GABA receptors and chloride channels. Receptor biochemistry and methodology, Vol 5 (Olsen RW, Venter JC, ed), pp 57-71. New York: Liss.

Kaneko A, Tachibana M (1986) Blocking effects of cobalt and related ions on the $\gamma$-aminobutyric acid-induced current in turtle retinal cones. J Physiol (I nnd) 373:463-479.

Karschin A, Wässle H (1990) Voltage- and transmitter-gated currents in isolated rod bipolar cells of the rat retina. Neurophysiology 63: 860-876.

Knoflach F, Rhyner T, Kellenberger S, Drescher U, Malherbe P, Sigel E, Möhler H (1991) The $\gamma 3$-subunit of the GABA receptor confers sensitivity to benzodiazepine receptor ligands. FEBS Lett 293:191194

Lasansky A (1992) Properties of depolarizing bipolar cell responses to central illumination in salamander retina. Brain Res 576:181-196.

Lukasiewicz PD, Werblin FS (1988) A slowly inactivating potassium current truncates spike activity in ganglion cells of the tiger salamander retina. J Neurosci 8:4470-4481.

Lukasiewicz PD, Werblin FS (1990) The spatial distribution of excitatory and inhibitory inputs to ganglion cells dendrites in the tiger salamander retina. J Neurosci 10:210-221.

Lukasiewicz PD, Werblin FS (1992) Light evoked, GABAergic synaptic inputs to $\mathrm{ON}$ bipolar cell terminals in the tiger salamander retina. Invest Ophthalmol Vis Sci [Suppl] 33:1172.

Lukasiewicz PD, Werblin FS (1994) A novel GABA receptor modulates synaptic transmission from bipolar to ganglion and amacrine cells in the tiger salamander retina. J Neurosci 14:1213-1223.

Macdonald RL, Barker JL (1979) Enhancement of GABA-mediated postsynaptic inhibition in cultured mammalian neurons: a common mode of anticonvulsant action. Brain Res 167:323-336.

Macdonald RL, Weddle MG, Gross RA (1986) Benzodiazepine, $\beta$-carboline, and barbiturate actions on GABA responses. In: GABAergic transmission and anxiety (Biggio $G$, Costa $E$, eds), pp 67-78. New York: Raven.

Macdonald RL, Rogers CJ, Twyman RE (1989) Barbiturate regulation of kinetic properties of the $\mathrm{GABA}_{\mathrm{A}}$ receptor channel of mouse spinal neurones in culture. J Physiol (Lond) 417:183-500.

Maguire G, Lukasiewicz P, Werblin F (1989a) Amacrine cell interactions underlying the response to change in the tiger salamander retina. J Neurosci 9:726-735.

Maguire G, Maple B, Lukasiewicz P, Werblin F (1989b) $\gamma$-Aminobutyric acid type $B$ receptor modulation of L-type calcium current at bipolar cell terminals in the retina of the tiger salamander. Proc Natl Acad Sci USA 86:10144-10147

Maple BR, Werblin FS (1986) Inhibitory feedback to bipolar cells in the tiger salamander retina. Soc Neurosci Abstr 12:634.

Marc RE (1986) Neurochemical stratification of the inner plexiform layer of the vertebrate retina. Vision Res 26:223-238.

Marc RE, Stell WK, Bok D, Lam DMK (1978) GABA-ergic pathways in the goldfish retina. J Comp Neurol 182:221-246.

Miller RF, Frumkes TE, Slaughter M, Dacheux RF (1981) Physiological and pharmacological basis of GABA and glycine action on neurons of the mudpuppy retina. II. Amacrine and ganglion cells. J Neurophysiol 45:764-782.

Mittman S, Taylor WR, Copenhagen DR (1990) Concomitant activation of two types of glutamate receptor mediates excitation of salamander retinal ganglion cells. J Physiol (Lond) 428:17/5-197.

Mosinger JL, Yazulla S, Studholme KM (1986) GABA-like immunoreactivity in the vertebrate retina: a species comparison. Exp Eye Res 42:631-644.

Muller JF, Marc RE (1990) GABA-ergic and glycinergic pathways in the inner plexiform layer of the goldfish retina. J Comp Neurol 291: 281-304.

Muller JF, Ammermüller J, Normann RA, Kolb H (1991) Synaptic in puts to physiologically defined turtle retinal ganglion cells. Vis Neurosci 7:409-429.

Murakami M, Shimoda Y, Nakatani K, Miyachi E, Watanbe S (1982) GABA-mediated negative feedback from horizontal cells to cones in carp retina. Jpn J Physiol 32:91 1-926.

Nelson R, Famiglietti EV Jr, Kolb H (1978) Intracellular staining reveals different levels of stratification for $\mathrm{ON}$ - and $\mathrm{OFF}$-center ganglion cells in cat retina. J Neurophysiol 41:472-483. 
Newland CF, Cull-Candy SG (1992) On the mechanism of picrotoxin on GABA receptor channels in dissociated sympathetic neurones of the rat. J Physiol (I ond) 447:191-213.

Nicoll RA (1972) The effects of anaesthetics on synaptic excitation and inhibition in the olfactory bulb. J Physiol (Lond) 223:803-814.

Nistri $\Lambda$, Sivilotti L (1985) An unusual effect of $\gamma$-aminobutyric acid on synaptic transmission of frog tectal neurones in vitro. Br J Pharmacol 85:917-921.

Polenzani L, Woodward RM, Miledi R (1991) Expression of mammalian $\gamma$-aminobutyric acid receptors with distinct pharmacology in Xenopus oocytes. Proc Natl Acad Sci USA 88:4318-4322.

Pourcho KG, Owczarzak M'I (1989) Distribution of GABA immunoreactivity in the cat retina: a light- and electron-microscopic study. Vis Neurosci 2:425-435.

Pourcho RG, Goebel DJ, McReynolds JS (1984) Autoradiographic studies of ${ }^{3} \mathrm{H}$-glycine, ${ }^{3} \mathrm{H}$-GABA and ${ }^{3} \mathrm{H}$-muscimol uptake in the mudpuppy retina. Exp Eye Res 39:69-81.

Pritchett DB, Seeburg PH (1991) $\gamma$-Aminobutyric acid type-A receptor point mutation increases the affinity of compounds for the benzodiazepine site. Proc Natl Acad Sci USA 88:1421-1425.

Pritchett DB, Lüddens H, Seeburg PH (1989) Type I and type Il $\mathrm{GABA}_{\mathrm{A}}$ benzodiazepine receptors produced in transfected cells. Science 245:1389-1392.

Qian H, Dowling JE (1993) Novel GABA responses from rod-driven retinal horizontal cells. Nature 361:162-164.

Ransom BR, Barker JL (1976) Pentobarbital selectively enhances GABA-mediated postsynaptic inhibition in tissue cultured mouse spinal neurons. Brain Res 114:530-535.

Shimada S, Cutting G, Uhl GR (1992) $\gamma$-Aminobutyric acid A or C receptor? $\gamma$-Aminobutyric acid $\rho 1$ receptor RNA induces bicuculline-, barbiturate, and benzodiazepine-insensitive $\gamma$-aminobutyric acid responses in Xenopus oocytes. Mol Pharmacol 41:683-687.

Sivilotti L, Nistri A (1989) Pharmacology of a novel effect of $\gamma$-aminobutyric acid on synaptic transmission of frog tectal neurones in vitro. Eur J Pharmacol 164:205-212.

Skrzypek J, Werblin FS (1983) Lateral interactions in the absence of feedback to cones. J Neurophysiol 49:1007-1016.

Stell WK, Ishida AT, Lightfoot DO (1977) Structural basis for Onand Off-center responses in retinal bipolar cells. Science 198:12691271.

Stewart WW (1978) Functional connections between cells as revealed by a highly fluorescent naphthalimide tracer. Cell 14:741-759.

Suzuki S, Tachibana M, Kaneko A (1990) Effects of glycine and GABA on isolated bipolar cells of the mouse retina. J Physiol (Lond) 421: 645-662.
Tachibana M, Kaneko A (1987) $\gamma$-Aminobutyric acid exerts a local inhibitory action on the axon terminal of bipolar cells: evidence for negative feedback from amacrine cells. Proc Natl Acad Sci USA 84: 3501-3505.

Weiland HA, Lüddens H, Seeburg PH (1992) A single histidine in $\mathrm{GABA}_{\mathrm{A}}$ receptors is essential for benzodiazepine agonist binding. $\mathrm{J}$ Biol Chem 267:1426-1429.

Werblin FS (1978) Transmission along and between rods in the tiger salamander retina. J Physiol (Lond) 280:449-470.

Werblin F, Maguire G, Lukasiewicz P, Eliasof S, Wu SM (1988) Neural interactions mediating the detection of motion in the retina of the tiger salamander. Vis Neurosci 1:317-329.

Wermuth CG, Bourguignon JJ, Schlewer G, Gies JP, Schoenfelder A, Melikian A, Bouchet MJ, Hantreux D, Molimard JC, Heulme M, Chambon J-P, Biziere K (1987) Synthesis and structure-activity relationships of a series of aminopyridazine derivatives of $\gamma$-aminobutyric acid acting as selective GABA-A antagonists. J Med Chem 30:239-249.

Wisden W, Seeburg PH (1992) GABA receptor channels: from subunits to functional entities. Curr Opin Neurobiol 2:263-269.

Wong-Riley MTT (1974) Synaptic organization of the inner plexiform layer in the retina of the tiger salamander. J Neurocytol 3:1-33.

Wu SM (1986) Effects of gamma-aminobutyric acid on cones and bipolar cells of the tiger salamander retina. Brain Res 365:70-77.

Wu SM (1992) Feedback connections and operation of the outer plexiform layer of the retina. Curr Opin Neurobiol 2:462-468.

Wyatt HJ, Daw NW (1976) Specific effects of neurotransmitter antagonists on ganglion cells in the rabbit retina. Science 191:204-205.

Yang C-Y, Yazulla S (1988) Localization of putative GABAergic neurons in the larval tiger salamander retina by immunocytochemical and autoradiographic methods. J Comp Neurol 277:96-108.

Yang C-Y, Lukasiewicz P, Maguire G, Werblin F, Yazulla S (1991) Amacrine cells in the tiger salamander retina: morphology, physiology, and neurotransmitter identification. J Comp Neurol 311:1-14.

Yang C-Y, Lin Z-S, Yazulla S (1992) Localization of GABA $A_{A}$ receptor subtypes in the tiger salamander retina. Vis Neurosci 8:57-64.

Yang XL, Wu SM (1991) Feedforward lateral inhibition: input-output relation of the horizontal cell to bipolar synapse in the tiger salamander retina. Proc Natl Acad Sci USA 88:3310-3313.

Yazulla S, Studholme KM, Wu J-Y (1987) GABAergic input to the synaptic terminals of $\mathrm{mb}_{1}$ bipolar cells in the goldfish retina. Brain Res 411:400-405. 